BMJ Open

Diabetes

Research

\& Care

\section{Insulin resistance versus insulin deficiency: evidence of racial differences in the pathogenesis of type 2 diabetes}

To cite: Garg R. Insulin resistance versus insulin deficiency: evidence of racial differences in the pathogenesis of type 2 diabetes. BMJ Open Diab Res Care 2021;9:e002261. doi:10.1136/ bmjdrc-2021-002261

Received 10 March 2021 Accepted 11 March 2021

\section{Linked}

- http://dx.doi.org/10.1136/ bmjdrc-2020-001988 > http://dx.doi.org/10.1136/ bmjdrc-2020-001927

Check for updates

(C) Author(s) (or their employer(s)) 2021. Re-use permitted under CC BY-NC. No commercial re-use. See rights and permissions. Published by BMJ.

Division of Endocrinology, Diabetes and Metabolism, University of Miami Miller School of Medicine, Miami, Florida, USA

Correspondence to Dr Rajesh Garg; rgarg@miami.edu
Racial differences in the incidence of type 2 diabetes (T2D) are well established. ${ }^{1}$ Southeast Asians living in Western countries as well as those living in their native countries are at a higher risk of developing T2D as compared with the Whites. ${ }^{2}{ }^{3}$ Similarly, Blacks and Native Americans in the USA are at a higher risk of developing T2D. ${ }^{4}$ Many studies have been conducted to understand the racial differences in the pathogenesis of T2D. Insulin resistance and insulin secretion defects have been the focus of most of these studies. South Asians, known to have more body fat for the same body mass index (BMI), have been shown to be more insulin resistant than Whites. ${ }^{5}{ }^{6}$ Previous studies did not find South Asians to have higher degrees of insulin deficiency than Whites. ${ }^{7}$ However, two epidemiological studies in the current issue of BMJ-DRC suggest otherwise. ${ }^{89}$

The first study compared the incidence of T2D in South Asians living in urban India and Pakistan with Blacks and Whites living in urban and suburban areas in the USA. ${ }^{8}$ South Asian data were obtained from the Cardiometabolic Risk Reduction in South Asia Study that recruited healthy subjects in 2010-2011 and followed them until 20162017 with a median follow-up of 4.8 years. Data for Blacks and Whites were obtained form the Atherosclerosis Risk in Communities (ARIC) Study that recruited healthy subjects in 1987 and followed them through 1996-1998 with a median follow-up of 8.8 years. The comparison was limited to ages $>45$ years as the ARIC Study recruited only people $>45$ years of age. As previously shown, South Asians had lower prevalence of obesity based on BMI and waist circumference than Blacks and Whites but higher incidence of diabetes compared with Whites. However, contrary to current concepts, South Asians were less insulin resistant and more insulin deficient than Blacks and Whites. The second study compared the South Asian population from the same study with Pima Indians enrolled before 1989 and followed for a median of 6.7 years. $^{9}$ This study included only the age groups 20-44 years as very few Pima Indians developed diabetes after age 45 years. South Asians were significantly less obese than Pima Indians based on BMI and had overall lower incidence of diabetes compared with Pima Indians. However, in those with BMI $<25 \mathrm{~kg}$ / $\mathrm{m}^{2}$, the risk of diabetes was five times higher in South Asian men than in Pima Indian men. Again, the study suggested relatively low insulin resistance but more insulin deficiency in South Asian men. In both studies, lower insulin secretion at baseline was a stronger predictor of T2D in South Asians while higher insulin resistance was a stronger predictor of diabetes in Blacks, Whites and Pima Indians. Based on these two studies, the authors conclude that the dominant pathophysiological defect in South Asians may be insulin deficiency rather than insulin resistance. This may change our understanding of the pathogenesis of T2D in South Asians and affect the strategies for screening, prevention or treatment of diabetes in South Asians.

Although the studies suggest that overall South Asian population is less insulin resistant and more insulin deficient, drawing mechanistic conclusions from these epidemiological studies is problematic. The epidemiological data can only provide a correlation and cannot be considered equivalent to the carefully conducted mechanistic studies. Moreover, there are multiple limitations of these data. The population enrolled in the South Asian study was more recent than the other populations with a gap of almost two decades. The only indices of insulin resistance and insulin secretion available in these studies were HOMA-IR and HOMA-B, respectively, that are less accurate in South Asians. ${ }^{10}$ Moreover, changes in insulin assays over the 
last two decades would have had a tremendous effect on these indices. Even the definition of diabetes has changed over time that may affect how carefully glycated hemoglobin was measured across the studies. Only the baseline data were considered for analysis in these studies, missing out the changes happening over time. Indices of insulin secretion and insulin resistance may change over time and may be completely different by the time of developing diabetes. All data were adjusted for BMI that is not a good marker of obesity in South Asians. ${ }^{11}$ Previous studies have shown that South Asians have more percentage of abdominal fat than other racial groups ${ }^{12}$ and lower cut-offs for obesity have been suggested. ${ }^{11}$

I think the data presented in these studies are hypothesis generating and should be interpreted with caution. Insulin resistance and defects in insulin secretion are essential components of the pathophysiology of T2D. Therefore, within any healthy population, those with lower insulin secretion or higher insulin resistance at baseline will be more likely to develop T2D. The statistical strength of associations will change depending on the identified confounders within that population and the statistical adjustments. For example, including visceral fat rather than BMI may change the results. The evidence presented by authors is an interesting hypothesis but it does not mount to the level of pathophysiological studies showing higher insulin resistance in South Asians than Whites. ${ }^{6}$ I would not consider the observations in these studies as clinically applicable or to have treatment implications at this time. There is definitely more to be learned about the racial differences in the pathogenesis of T2D.

Funding The author has not declared a specific grant for this research from any funding agency in the public, commercial or not-for-profit sectors.

Competing interests None declared.

Patient consent for publication Not required.

Provenance and peer review Commissioned; internally peer reviewed.
Open access This is an open access article distributed in accordance with the Creative Commons Attribution Non Commercial (CC BY-NC 4.0) license, which permits others to distribute, remix, adapt, build upon this work non-commercially, and license their derivative works on different terms, provided the original work is properly cited, appropriate credit is given, any changes made indicated, and the use is non-commercial. See: http://creativecommons.org/licenses/by-nc/4.0/.

\section{REFERENCES}

1 Cheng YJ, Kanaya AM, Araneta MRG, et al. Prevalence of diabetes by race and ethnicity in the United States, 2011-2016. JAMA 2019;322:2389-98.

2 Kanaya AM, Wassel CL, Mathur D, et al. Prevalence and correlates of diabetes in South Asian Indians in the United States: findings from the metabolic syndrome and atherosclerosis in South Asians living in America study and the multi-ethnic study of atherosclerosis. Metab Syndr Relat Disord 2010;8:157-64.

3 Ramachandran A, Snehalatha C, Kapur A, et al. High prevalence of diabetes and impaired glucose tolerance in India: national urban diabetes survey. Diabetologia 2001;44:1094-101.

4 Centers for Disease Control and Prevention. National diabetes fact sheet: national estimates and general information on diabetes and prediabetes in the United States, 2011. Atlanta, GA: US department of health and human services, centers for disease control and prevention, 2011: 201. 2568-9.

5 Raji A, Seely EW, Arky RA, et al. Body fat distribution and insulin resistance in healthy Asian Indians and Caucasians. J Clin Endocrinol Metab 2001;86:5366-71.

6 Nair KS, Bigelow ML, Asmann YW, et al. Asian Indians have enhanced skeletal muscle mitochondrial capacity to produce ATP in association with severe insulin resistance. Diabetes 2008;57:1166-75.

7 Hulman A, Simmons RK, Brunner EJ, et al. Trajectories of glycaemia, insulin sensitivity and insulin secretion in South Asian and white individuals before diagnosis of type 2 diabetes: a longitudinal analysis from the Whitehall II cohort study. Diabetologia 2017;60:1252-60.

8 Narayan KMV, Kondal D, Daya N. Incidence and pathophysiology of diabetes in South Asian adults living in India and Pakistan compared to US blacks and whites. BMJ Open Diab Res Care 2021.

9 Narayan KMV, Kondal D, Kobes S. Incidence of diabetes in South Asian young adults compared to Pima Indians. BMJ Open Diab Res Care 2021.

10 Muniyappa R, Irving BA, Unni US, et al. Limited predictive ability of surrogate indices of insulin sensitivity/resistance in Asian-Indian men. Am J Physiol Endocrinol Metab 2010;299:E1106-12.

11 Chiu M, Austin PC, Manuel DG, et al. Deriving ethnic-specific BMI cutoff points for assessing diabetes risk. Diabetes Care 2011;34:1741-8.

12 Lear SA, Humphries KH, Kohli S, et al. Visceral adipose tissue accumulation differs according to ethnic background: results of the multicultural community health assessment trial (M-CHAT). Am J Clin Nutr 2007;86:353-9. 